\title{
Strategic Fiscal Interaction across Borders: \\ Evidence from French and German Local Governments along the Rhine Valley
}

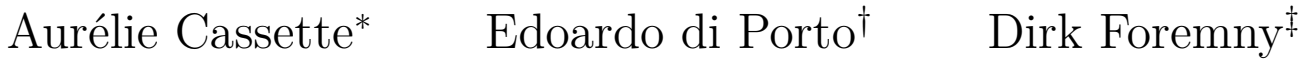

This Version: December 2010

\begin{abstract}
This article contributes to the literature on local tax interactions, with an innovative focus on interactions of local governments across national borders. We use a panel data set of the municipalities in France and in Germany along the Rhine Valley to estimate an empirical model of strategic interactions between French and German local jurisdictions over the period 2000-2007. Local governments in either country can influence the overall tax burden of firms. We estimate panel models in which we distinguish between the influence of competing municipalities which belong to the same country and the effect of competing municipalities which belong to different countries, sharing a border. Our estimations show that local jurisdictions along the border choose their business tax rates only by looking at their domestic neighbors. The foreign local fiscal policy does not have an impact on the domestic tax setting behavior.
\end{abstract}

Keywords: fiscal interactions, tax competition, spatial econometrics, fiscal federalism JEL Classification Numbers: H7, H71, H87, H2, H25, C23

\footnotetext{
*University of Lille, Equippe, France, e-mail: aurelie.cassette@univ-lille1.fr † University of Lille, Equippe, France, e-mail: edoardo.diporto@univ-lille1.fr

$\ddagger$ University of Bonn, Germany, e-mail: dforemny@uni-bonn.de
} 


\section{Introduction}

Over the past decades the mechanisms driving strategic fiscal policy interactions between governments have received increasing attention in both, academic literature, and in the public debate. While the latter is mainly driven by discussions about tax evasion and international tax havens, the early academic literature focused on local governments within one country. The literature on fiscal federalism has emphasized that two kinds of externalities can result from the existence of governments operating in a multi-tiered system. On the one hand, a horizontal externality can arise when fiscal choices of one local level jurisdiction affect fiscal decisions made by other competing jurisdictions at the same level of government. This happens for instance when governments try to attract a mobile tax base (see Wilson (1999) for a survey) or the politicians attempt to maximize their reelection prospects (Besley and Case, 1995). On the other hand, a vertical externality can arise because of fiscal interactions between different layers of government. This is particularly the case when those governmental layers share the same tax base.

The majority of empirical studies focus on the horizontal tax interdependencies between local governments that belong to the same national country. In addition, a small and recent literature has spent attention on fiscal interactions between different countries. Public debate, however, has also focused on international tax competition between central governments, but generally neglects internal country differences on the sub-national level. The French President recently stated that the differences between the French and the German tax systems put France at a disadvantage. "I cannot accept the disadvantages to our competitive potential compared to our most important client and most important trading partner", Sarkozy said in a television interview. Our measure of the overall tax burden for companies shows, that allowing for variation in sub-national tax rates, some French regions are remaining competitive compared to some German jurisdictions in our sample.

The existing empirical literature on horizontal fiscal policy interactions is strictly distinguishable by the level of government where the interaction takes place. Hence, till now interactions are either investigated domestically on the local level or internationally on the central level. Our research instead acknowledges that local level government tax interactions can occur across national borders.

Tax systems in Europe have been shaped over the last decades by two main trends, the European Integration process and decentralization. When national governments decide to transfer competencies to sub-national governments, they have to find a way to finance them. Two possibilities exist: an increase in tax autonomy by the devolution of local taxing powers through new tax instruments or an increase in transfers from the central government. 
Endowing local governments with a specific local tax is not without consequences, especially when this tax affects a mobile tax base. In addition, the process of economic integration among the countries of the European Union raises numerous questions of fiscal coordination among member states. Our point is that in a highly integrated economic area with an Internal Market, like the European Union, products and factors are free to move across borders. While indirect taxation is harmonized by several agreements, factor income taxation is not. Indeed, in the absence of taxation and other infrastructural or institutional barriers, investment would take place where production costs are lower. The introduction of taxes distorts this decision, since the firm is lured by the location where after-tax profits are the highest. For this reason, company taxation has attracted a great deal of attention as an important element for the operability of the Internal Market. Thus, an investigation of interactions between local governments that have a substantial degree of discretion over taxes in different countries seems to be both, an interesting, but also an empirical demanding question.

Beside local taxation, many elements of the tax system affect a firm's net-of-tax profits. These elements vary only across countries, not across jurisdiction in a given country. When foreign jurisdictions, with their different taxation systems, are regarded as well, elements of the tax code adopted by higher level governments come into play, since they are no longer equal for all sub-national authorities. Local peculiarities finally generate a very multifaceted bandwidth of potential after-tax profits in different regions beyond national borders. Nevertheless, the scope of lower level governments to attract mobile factors is limited. It is very unlikely that communities in Lapland observe and react to fiscal choices undertaken in Andalusia. The literature on local interactions reveals that proximity is an important element, and only jurisdictions within a certain distance matter. The second point is that tax interactions are only likely to occur when subnational governments are equipped with fiscal instruments on which they have a high degree of discretion, and if they are able to influence significantly the after-tax profits of firms.

The German-French context offers an interesting example, since both conditions are fulfilled. In both countries the local level has an intense impact on the overall tax burden of firms. French and German municipalities can set a tax on business activities, beside a local tax on properties. These taxes generate an additional tax burden that firms have to pay. Furthermore, Germany and France share a large common border along the Rhine Valley. Therefore, our empirical strategy disentangles interactions between local governments of these two particular countries in that region.

Our main results show that spatial correlation in the taxes set by local governments is solely driven by domestic effects. Furthermore, we are able to distinguish between an effect due to the border or due to one that arises because of infrastructural disadvan- 
tages. In our particular case, the Franco-German border coincides with the Rhine River. Crossing the Rhine is only possible where infrastructure, such as ferries or bridges, allows that. Taking this into account does not change the main finding of this paper. Local interactions are a domestic issue.

This paper is organized in the following way: The next section provides facts about subnational taxes in France and Germany. Section three summarizes the existing empirical literature. In section 4, we present the empirical specification and the peculiarities of our specific context. Our dataset is introduced in section 5. The results are presented in section 6 . The paper comes to a close in the last section.

\section{Subnational Tax Systems in France and Germany}

Almost all Member States of the European Union are characterized by a trend towards decentralization over the last decades. Competencies have been transferred from the central level to sub-national governments. In turn, those governments have sometimes been equipped with tax instruments to generate the revenues to fulfill their responsibilities. Local authorities can substantially influence the overall tax burden of firms in France and in Germany, but it should be acknowledged that the available tax instruments are different. This section explains the characteristics of the French and German local fiscal system, respectively.

French local jurisdictions can influence the professional tax (taxe professionelle, tp) and German municipalities can control the local trade tax (Gewerbesteuer, gs). Local governments can also choose a tax rate on real estate in both countries. The share of revenues that arise from these tax sources is depicted in figure 1. Municipalities in both countries have to generate a substantial share of revenues on their own, measured as the total share of revenues. In 2007, Germany had about one quarter of the share of own resources in total local revenues and France had more than one third for their sub-national governments.

[Figure 1 about here]

Standard models of tax competition predict that local policymakers can use these instruments to make their territory attractive for investment. However, beside the fact that local governments can decide on the tax rate, both systems have important differences that exist on the sub-national (different tax base) and national (especially in capital allowances) level, which requires further explanation. The aim of this section is to show how we translate the formal tax code on the local level into our measure of the tax burden. Tax systems have been subject to several reforms and changes in either country. We describe the rules valid during the sample period of 2000-2007 in the following part. 


\subsection{Local Characteristics: The French Case}

The structure of French sub-national governments has four tiers. The lowermost level consists of around 36,000 municipalities, divided into more than 13,000 groups of municipalities (known as Etablissements Publics de Coopération Intercommunale). The middletier consists of 96 departments while the top level is formed by the 22 regions. Our paper focuses on the lowest level of government.

Business is taxed on all governmental levels. Beside the national corporate income tax (impôt sur les sociétés, cit), corporate taxpayers are subject to two sub-national taxes: a local business tax (taxe professionnelle, tp) and a real estate tax (taxe foncière, $\mathrm{tf}$ ). The statutory rates $t_{t p}$ and $t_{t f}$ are set annually by the local authorities and vary between regions, departments and municipalities. The consolidated tax rate is the sum of rates across sub-national levels.

The groups of municipalities may choose to set a single business tax rate (taxe professionnelle unique) which applies to all municipalities belonging to the inter-municipal group or to apply an additional tax rate on each of the local taxes. In the first case, the municipalities do not set their own business tax rate. The municipal cooperation therefore acts as merging jurisdictions. In the second case, a new level of local government sets their own additional tax rate, which strengthens tax base sharing.

The professional tax is a local business tax levied on tangible fixed assets, like machinery, and on buildings. The tax base is the rental value $\sigma$ of the tangible fixed assets used for the purpose of the business. ${ }^{1}$ For buildings, tax law defines the rental value as $8 \%$ of the value of the buildings, whereas for machinery, the rental value is $16 \%$ of the value. In either case a general deduction of $16 \%$ applies and the local tax is deductible from the corporate income tax $\left(t_{c i t}\right)$. Therefore, the effective rate is given by

$$
T_{t p}=\left(1-t_{c i t}\right) \sigma(1-0.16) t_{t p}
$$

The taxe foncière as the real estate tax is levied on the owner of residential properties situated within France. The tax base is obtained after applying a 50\% allowance to the rental value. The effective rate accounts for the deductibility from corporate income tax

$$
T_{t f}=\left(1-t_{c i t}\right) \sigma t_{t f}
$$

\footnotetext{
${ }^{1}$ We adopt this parameter from Devereux et al. (2008), see table 8 in A for details.
} 


\subsection{Local Characteristics: The German Case}

Germany has two sub-national governmental levels: sixteen federal states (Bundesländer) and around 12,000 municipalities or cities as the lowest level of government. The German framework of public finance is a complex system, based on revenue-sharing and equalization schemes between all governmental layers. The profits of corporations in Germany are subject to two different taxes. The central government levies a tax on corporate profits (Körperschaftsteuer, cit). Revenues are shared with the federal states since they have no power to tax business activities.

The trade tax (Gewerbesteuer, gs) is the German local business tax and is a tax on profits earned by corporations and self-employed persons. A share from this tax has to be given to the states and the federal level. The tax base consists of profits of business enterprises as determined under income tax law or corporation tax law. Each local authority has discretion over a so called collection rate $c_{g s}$. These collection rates can be transformed into a ordinary statutory tax rate expressed in percentages. Therefore, the collection rate has to be devided by 100 and multiplied by a specific value (5\% under our assumptions $)^{2}$ designated by law which implements a degree of progressivity into the tax code. In addition, the tax liability is deductible from its own tax base and the tax base of the corporate income tax (see Scheffler (2002) for details of the German tax code). The adjusted effective tax rate can then be calculated by

$$
\begin{aligned}
T_{g s} & =\frac{5}{100} \cdot \frac{c_{g s}}{100} \cdot\left(1-T_{g s}\right) \cdot\left(1-t_{c i t}\right) \\
\Leftrightarrow T_{g s} & =\frac{c_{g s}}{2000+c_{g s}}\left(1-t_{c i t}\right)
\end{aligned}
$$

A second local tax is the municipal real estate tax (Grundsteuer, pt). Each municipality has the right to choose a collection rate for this tax $c_{p t}$ and could distinguish between agricultural and other areas. We will focus on the latter. The effective rate accounts for the deductibility of real estate taxes from corporate income taxation $\left(t_{c i t}\right)$. It is determined by

$$
T_{p t}=\sigma\left(1-t_{c i t}\right) c_{p t}
$$

Other studies on international tax-comparisons, for example Devereux et al. (2008), assume that the tax base of the real estate tax amounts to $25 \%$ of the acquisition costs, see table 8 in A for details.

These elements are the main ingredients for the calculation of our measure of the local

\footnotetext{
${ }^{2}$ We focus in our setting on the highest multiplier, which is in fact applied to all incorporated firms. Their share of the total tax base in 2004 was about 55\%. Nevertheless, results do not change for any other value since this multiplier is just a linear transformation.
} 
tax burden. We compute municipal specific effective average tax rates and take the elements that vary between sub-national governments into account. The computation is explained in more detail in A. The resulting tax rates are presented when we introduce our data set. Nevertheless, it is interesting to note at this stage that tax rates vary substantially, and that the local impact on the tax burden is not small in both countries.

\section{Strategic Interactions in France and Germany}

The existence of strategic interactions among fiscal authorities is a common prediction of the tax competition (surveyed by Wilson (1999)) and the yardstick competition (Besley and Case, 1995) literature. The reason behind the strategic component in tax rates is an outflow of mobile capital in the former case, while under yardstick competition incentives of politicians are causing the interactions. The empirical literature in this field aims at testing for the existence of strategic interactions among governments. These models are usually implemented empirically through the estimation of a fiscal reaction function, where the optimal tax rate in a jurisdiction depends on the tax rates in nearby jurisdictions (view Revelli (2006) for a survey of empirical models).

Most subsequent empirical studies concentrate on tax interactions among local jurisdictions within a country or among the states within a federal country (see Brueckner (2003) for a survey). In addition, a more recent empirical literature focused on international tax competition (Redoano, 2007; Devereux et al., 2008; Cassette and Paty, 2008). Those studies show that industrialized countries compete over statutory and effective average tax rates of the corporate tax. It has been argued that tax competition (and not yardstick competition) over corporate taxes is the most plausible explanation for these results, since most voters are ignorant of the domestic corporate tax rate and therefore do not take them into account when evaluating the performance of the incumbent. However, for income taxes and public expenditures, the existing fiscal interactions would possibly be the result of yardstick competition.

Hereafter, we will only discuss the empirical tests centered at the municipal level in France and Germany. Most papers dealing with other countries ${ }^{3}$ find empirical evidence of positive interactions among sub-national governments using various sets of data on local property or business tax rates.

The local business tax is the major source of tax revenue for local governments in France. Hence, it is not surprising that empirical tests are mainly concerned with this

\footnotetext{
${ }^{3}$ Including those of Brett and Pinkse (2000) in Canada, Heyndels and Vuchelen (1998) in Belgium, Brueckner and Saavedra (2001) in the US, Revelli (2001) in the UK, Feld and Reulier (2009) in Switzerland, Solé-Ollé (2003) in Spain, Bordignon et al. (2003) in Italy, Edmark and Ågren (2008) in Sweden, and Allers and Elhorst (2005) in the Netherlands
} 
tax. ${ }^{4}$ All the papers dealing with spatial interactions at the municipal level found evidence of tax interactions. Jayet et al. (2002) only focus on horizontal interactions when investigating tax interactions in France. They attempt to check the existence of tax mimicking between municipalities belonging to so-called employment zones $^{5}$ in the region Nord-Pas de Calais (Northern France). Tax interactions among neighbor municipalities are found in urban areas but not in rural ones. Charlot and Paty (2007, 2010) study spatial fiscal interactions among municipalities controlling for vertical fiscal interactions and taking into account agglomeration forces. They also observe significant mimicking behavior between jurisdictions when choosing their local business tax rate, and vertical interactions between municipalities and regions.

While the academic literature in the French setting is quite rich, less attention has been spent on strategic interactions in Germany. In a panel-data set from a German state (Baden-Wuerttemberg), Buettner (2001) finds that tax rates are strategic complements, i.e. that the best response to an increase in adjacent municipalities' tax rates is to raise the own tax rate as well. The prediction that the tax base is not only affected by the own tax rate but also by the tax rate established in neighboring jurisdictions is verified, among others, by Buettner (2003) for German local governments, but the effect is rather small. Interestingly, the regional sample of these studies is located in a federal state that includes the border-region and a set of dummies is used to pick up regions particularly exposed to international competition. Results suggest that within a bandwidth of 30 kilometers distance to the border, significant effects are at work. However, this is not worked out in detail since the data-set ends at the German frontier.

To our knowledge, no empirical study tests the existence of local tax interactions across national borders. From the theoretical context, as long as capital is perfectly mobile, there exists no reason why politicians and voters should only take the behavior of adjacent municipalities of one's own country into account. Furthermore, one should expect that the introduction of a single currency leads to higher mobility within Europe and higher tax interactions between countries to attract tax bases. Since this effect has already been found at the national level, a test for international interactions on the local level is a gap in the literature, that we want to fill with our contribution.

\footnotetext{
${ }^{4}$ Empirical studies using French data have also been performed at departmental level (Leprince et al., 2007; Dubois et al., 2007) and regional level (Feld and Rocaboy, 2003).

${ }^{5}$ These zones correspond to a statistical category defined administratively by the central government that gathers municipalities that are geographically closed to each other and quite homogeneous in terms of socio-economic characteristics.
} 


\section{From Theory to Empirics}

This section describes how we get from theory to empirical models that are able to test our main hypotheses. While theoretical arguments do not differ much from standard models of tax competition, our empirical strategy is specific to our context and distinct from previous papers regarding local interactions.

\subsection{Theoretical Background}

Following Brueckner (2003), the residents' utility of municipality $i\left(u_{i}\right)$ depends on their private consumption $\left(c_{i}\right)$ and on the quantity of public goods provided by the local government $\left(g_{i}\right)$, thus

$$
u_{i}=u\left(c_{i}\left(k_{i}\right), g_{i}\left(k_{i}\right) ; X_{i}\right)
$$

where $X_{i}$ is a vector of characteristics of the jurisdiction, such as demographic attributes, reflecting preferences and needs of the local population. $k_{i}$ is the resource used as the tax base in that jurisdiction (capital used by firms for production). The demand for capital depends on the fiscal environment in the jurisdiction because firms maximize after-tax profits. As in the basic model of Zodrow and Mieszkowski (1986), a perfectly competitive firm produces output by a twice differentiable, constant returns to scale production function under the assumption that labor is locally fixed:

$$
f_{i}\left(k_{i}, l_{i}\right) \text {, with } l=1 \text {, and } f_{k}>0>f_{k k}
$$

As discussed above, sub-national governments in France and Germany can tax a different local tax base. The French local tax could be seen as a unit capital tax while the German local business tax is a tax on profits. After local-tax profits of firms are thus different in both countries. Maximizing the respective profit function yields the profit maximizing first order conditions for the demand for capital in either country: ${ }^{6}$

$$
\frac{\partial \Pi_{i}}{\partial k_{i}}= \begin{cases}f^{\prime}\left(k_{i}\right)\left(1-T_{g s}\right)-r=0 & \text { for Germany } \\ f^{\prime}\left(k_{i}\right)-T_{t p}-r=0 & \text { for France }\end{cases}
$$

Under the assumption that capital is perfectly mobile, equilibrium of the capital market implies that the after-tax rate of return equalizes across jurisdictions, independent of the applied tax instrument. Furthermore, Lockwood (2004) shows that, although a jurisdiction cares about which tax instrument its rivals use, the jurisdiction itself is indifferent

\footnotetext{
${ }^{6}$ These equations are simplified since we only take the local business taxes into account. However, the underlying problem is similar for other taxes.
} 
between these instruments since for any tax rate on profits a revenue equivalent unit rate exists. Hence we define $\tau$ as the effective average tax rate, that is the tax burden for a one-unit hypothetical investment project. We can transform the German profit tax into a per unit tax by writing $T_{g s}=\frac{\tau}{f^{\prime}\left(k_{i}\right)}$. Since taxes in France are already expressed per unit, the equilibrium on the capital market for both countries implies

$$
f^{\prime}\left(k_{i}\right)=r+\tau
$$

as the profit-maximizing condition for jurisdictions in both countries. The tax rate $\tau$ is the measure of the tax burden which we use in our empirical estimations. Beside the transformation between different tax bases, this measure is able to depict further elements of the tax code. For example, the coexistence of real estate taxes on the municipal level is regarded in this measure.

Now define $\varphi$ as the inverse of $f^{\prime}\left(k_{i}\right)$ and the demand for capital is given by

$$
k_{i}=\varphi(r+\tau)
$$

Market clearing requires that

$$
\sum_{i=1}^{m} \varphi(r+\tau)_{i}+\sum_{i=m+1}^{n} \varphi(r+\tau)_{i}=\sum_{i=1}^{n} k_{i}
$$

where $m$ is the share of municipalities in one of the two respective countries. The last two equations show that the capital demand depends on all tax rates and differentiation of $(4,5)$ gives $\frac{\partial \varphi}{\partial \tau_{i}}<0$, i.e. capital flees by an increase of the effective average tax rate.

Maximization of (1) subject to the capital demand equilibrium (5) and (4) yields that the optimal tax policy depends on tax rates elsewhere and own local characteristics. The resulting reaction function is given by

$$
\tau_{i}=\tau\left(\tau_{-i}, X_{i}\right)
$$

where the notation $-i$ indicates all municipalties other than $i$.

This result, however, holds only if and only if capital is perfectly mobile between the two countries. Another point of view is that capital first adjusts on the country level, i.e. the two countries compete over their shares, say $\alpha$ and $(1-\alpha)$. Once proportions are fixed, each municipality can only try to be attractive so that the firm prefers to locate in their area rather than in a nearby municipality of the same country. In that case 
interactions reduce to the standard within country case and domestic tax rates are only a function of nearby domestic policy choices.

$$
\begin{aligned}
\tau_{i \in[1, m]} & =\tau\left(\tau_{-i \in[1, m]}, X_{i}\right) \\
\tau_{i \in[m+1, n]} & =\tau\left(\tau_{-i \in[m+1, n]}, X_{i}\right)
\end{aligned}
$$

Proposition 1. In the absence of restrictions to the mobility of capital, tax rates are a function of all other domestic and foreign tax rates, irrespective of the tax base. As soon as capital is once fixed in either country, only domestic interactions take place.

Hence, a local jurisdiction in either country could interact with the fiscal policy enacted in local jurisdictions of both countries. To test the existence of tax interactions among local governments, we estimate reduced-form tax reaction functions which allow us to distinguish the effects between countries from those effects arising within one country. These estimations could also be seen as an indirect test of the mobility of capital between the two regions on their respective side of the frontier. We present our estimation strategy in the following section.

\subsection{Identification}

Our main question of interest is whether there is any correlation between local tax rates across national borders. Existing empirical work that disentangles the effects between different sub-groups utilized fixed effects methods (e.g. Cassette and Paty (2008) with GMM methods, Gérard et al. (2010) with ML estimators).

To test the existence of tax interactions among local governments, we need to estimate the reduced-form reaction function, which can be expressed in a linear form such as

$$
\tau_{i t}=\rho \sum_{j \neq i} w_{i j} \tau_{-i, t}+X_{i t} \beta+\eta_{i}+v_{t}+\varepsilon_{i t}
$$

where $\rho$ is the parameter associated to the weighted average of competing governments' tax rates, $\beta$ is the parameter associated to the socio-economic characteristics of municipality $i, \eta_{i}$ is a municipal fixed effect, $v_{t}$ is a time fixed effect and finally $\varepsilon_{i t}$ is a random term. The weighting scheme $w_{i j}$ defines, as usual in applied spatial econometrics, which other local governments have to be regarded as neighbors. We describe the choice of weights in more detail in the following section, since our context requires a careful construction of the respective elements.

In order to distinguish the influence of competing municipalities that belong to the same country from the effect of competing municipalities that do not belong to the same 
country, we need to consider three different cases regarding the influence of competing municipalities' tax rates. The empirical reaction function can be written as

$$
\begin{aligned}
\tau_{i t} & =\rho_{1} \sum_{j \neq i} w_{i j}^{d e} \tau_{-i \in[1, m], t} \\
& +\rho_{2} \sum_{j \neq i} w_{i j}^{f r} \tau_{-i \in[m+1, n], t} \\
& +\rho_{3} \sum_{j \neq i} w_{i j}^{b o r d e r} \tau_{-i, t}+X_{i t} \beta+\eta_{i}+v_{t}+\varepsilon_{i t}
\end{aligned}
$$

where $\rho_{1}$ is the parameter associated to the weighted average of other jurisdictions' tax rates that belong to Germany if municipality $i$ is also a German one. $\rho_{2}$ instead is the parameter associated to the weighted average of other jurisdictions' tax rates that belong to France if municipality $i$ belongs to France. All elements in the weighting matrix $w_{i j}^{d e}$ and $w_{i j}^{f r}$ are equal to zero if the $i$ and $j$ elements are from different countries. The coefficient $\rho_{3}$ instead measures the effect associated to the weighted average of other jurisdictions' tax rates that do not belong to the same country as country $i$. Hence, the elements of the weighting matrix $w_{i j}^{\text {border }}$ are equal to zero if municipality $i$ and $j$ are associated with the same country and different from zero otherwise. ${ }^{7}$

Parameters $\rho_{1}, \rho_{2}$ and $\rho_{3}$ will thus measure the degree of tax interactions respectively among German municipalities, among French municipalities, and finally between French and German municipalities. In practice, we are decomposing the spatial process in three parts. This matrix decomposition was first used by Gérard et al. (2010) and does not apply any standardization of the individual sub-matrices.

Since interactions are supposed to be strategic, the tax rates are jointly determined and thus endogenous. Ordinary least squares (OLS) estimates of the parameters of equation (7) are inconsistent (Anselin, 1988). In order to deal with the endogeneity of competing municipalities' tax variables on the right hand side, we use an instrumental variables approach as proposed by Kelejian and Robinson (1993) and Kelejian and Prucha (1998). We use spatial lags of some covariates as well as the one period lag of the spatially lagged tax rates as instruments. The validity of the set of instruments is verified by a Hansen-J test after each regression. We investigate the appropriateness of lags as instruments by conducting a difference in Hansen test on this subset.

It is worth to note that tax rates in such a framework could be serially correlated, for example because changes in tax rates might be costly to implement by governments. We estimate the covariance matrix of the parameters in model 7 according to Newey and West (1987) with standard errors that are robust to both, heteroskedasticity and

\footnotetext{
${ }^{7}$ In matrix form, the initial model $\tau=\rho W \tau+\beta X+\varepsilon$, becomes $\tau=\rho_{1} W^{d e} \tau+\rho_{2} W^{f r} \tau+\rho_{3} W^{b o r d e r} \tau+$ $\beta X+\varepsilon$ with $W=W^{\text {de }}+W^{f r}+W^{\text {border }}$.
} 
autocorrelation (HAC).

To capture possible dynamic effects, we reestimate the model and include a time-lagged dependent variable to control for persistency in tax rates

$$
\begin{aligned}
\tau_{i t}=\gamma \tau_{i, t-1} & +\rho_{1} \sum_{j \neq i} w_{i j}^{d e} \tau_{-i \in[1, m], t} \\
& +\rho_{2} \sum_{j \neq i} w_{i j}^{f r} \tau_{-i \in[m+1, n], t} \\
& +\rho_{3} \sum_{j \neq i} w_{i j}^{b o r d e r} \tau_{-i, t}+X_{i t} \beta+\eta_{i}+v_{t}+\varepsilon_{i t}
\end{aligned}
$$

The presence of the lagged dependent variable in equation 8 together with fixed effects and spatial lags requires the use of a generalized method of moments (GMM) estimator as suggested by Kukenova and Monteiro (2009) and applied in Cassette and Paty (2008), namely difference GMM (Arellano and Bond, 1991). The difference GMM estimator corrects for the endogeneity of the spatial lags. This estimator takes first differences to estimate the equation and uses lags of the dependent variables from at least two periods earlier, as well as lags of the right-hand side exogenous variables, as instruments.

The robustness of our regression is evaluated with usual tests after difference GMM estimations. Again, a Hansen-J test examines the hypothesis that the instruments are not correlated with the residuals. A second required test is proposed by Arellano and Bond (1991). This test, denoted AR(2), examines the hypothesis that the residuals from the first-differenced estimating equation are not second-order correlated. Both statistics are necessary to confirm the validity of the instruments used. An accurate choice of the instruments solves the problem of the instruments proliferation (Roodman, 2009), and the number of instruments we use does not impair the power of the Hansen test statistic.

\section{Data}

Subject to our study are local governments in the Franco-German border area. In order to focus on the effects arising due to possible interactions across this border, we include all municipalities located within a certain bandwidth (20 and $30 \mathrm{~km}$ distance of a municipalities' centroid) to the border into our sample. We focus on those local governments that belong either to the German federal state of Baden-Wuerttemberg or those in the French departments Bas-Rhin and Haut-Rhin. Figure 2 depicts the region from which we draw our sample. The shaded areas represent our two distance based sub-samples, respectively. On the French side, local governments belonging to a City Union that chooses the single tax rate regime are aggregated since fiscal policy decisions are taken jointly. We have eventually 347 or 602 municipalities included in the small or large sample, respectively. 
[Figure 2 about here]

Our dataset provides information on an annual basis over the period 2000-2007 and could be divided into two broad categories: taxation and socio-economic variables. Before we describe that part of our dataset, we demonstrate how geographical features and proximity is introduced in our setup via spatial weights.

\subsection{Spatial Weights}

According to Tobler (1970) "everything is related to everything else, but near things are more related than distant things." In the literature on tax competition, governments are assumed to take account of the flight of capital to neighboring jurisdictions caused by an increase in its own tax rate. Thus, a scheme that assigns weights based on geographical distance or contiguity is frequently used in the empirical literature.

First, based on the Euclidian distance, we treat different numbers of close-by jurisdictions as neighbors. The weighting scheme $W^{N N 6}$ for instance establishes a connection to the six closest municipalities and assigns a weight of $w_{i j}^{N N 6}=1 / 6$ to each of them. In the context of international interactions only jurisdictions from the foreign country are regarded as potential candidates for neighbors. In other words, each domestic municipality is connected to only those on the other side of the border. ${ }^{8}$

Another possibility is to express neighborship in terms of pure air-line distance. This scheme is given by the weight matrix $W^{D I S T}$ and imposes a smooth distance decay, with weights given by $w_{i j}^{D I S T}$, where $d_{i j}$ is the Euclidian distance between the centroid of municipality $i$ and municipality $j$, after standardization

$$
w_{i j}^{D I S T}=\frac{1 / d_{i j}}{\sum_{j} 1 / d_{i j}}
$$

We use cut-off criteria to exclude municipalities from beeing neighbors if they exceed either a $15 \mathrm{~km}$ or a $30 \mathrm{~km}$ distance threshold.

A nice feature of our dataset is that the border between Germany and France coincides with the Rhine River. This allows us to reformulate the weighting scheme in order to take the local infrastructure into account. Crossing the border is only possible where bridges or ferries establish a connection between the two countries. Our weights are calculated as the nearest possible way to cross the river from municipality $i$ with dry feet to reach municipality $j$ in the other country. A comparison of the $\rho_{3}$ parameter with pure distance and this measure could reveal whether actually the border itself or the infrastructure to secure mobility is important for tax rate interactions.

\footnotetext{
${ }^{8} w_{i j}=0$ if $i$ and $j$ are from the same country but can be different from zero otherwise.
} 


\subsection{Taxation data}

Taxation data is the core element of our dataset. We compute effective average tax rates (EATR) in order to depict the overall burden borne by firms within a certain fiscal environment. These measures are often applied in studies on international tax comparisons and the tax competition literature on the national level. We apply the framework developed by Devereux and Griffith (2003).

The rates calculated by this method basically arise from taking a specific form of investment, using specific sources of financing. The methodology adopted to compute these effective average tax rates is provided in A. Since we are interested in the part on which a local government can have an impact upon, we calculate the local EATR by setting all elements of the tax code, not under local discretion, equal to zero. By doing so, in the end our measure turns out to be highly correlated with local statutory tax rates. We expect a positive impact of neighbors' tax rates on the own tax rate, as shown in earlier contributions. However, we are interested in the impact of foreign fiscal policy choices on the domestic decisions taken in the home country.

In addition, we introduce a measure of the tax burden due to higher level governments, including the national corporate income tax. This is included to take into account potential vertical interactions in the setting of the local tax rates. In contrary to the calculation of the local tax rate, we here set everything under the discretion of the bottom level equal to zero. This procedure permits us to get a comparable measure of the tax burden for the local and the higher levels, because in France the tax base differs between the central tax on firms (corporate income tax based on profits) and the sub-national taxes. Moreover, effective tax rates permit to account for differences between the two countries in the composition of the corporate income tax base (especially in capital allowances).

[Figure 3 about here]

Figure 3 puts strength on the argumentation that local governments in the two respective countries have the possibility to interact with their fiscal policy instruments. Each dot represents the overall effective average tax rate, either in France (gray) or in Germany (black). Since these two are spread on the same interval after 2000, municipalities have potentially the power to compete with their foreign neighbor.

Nevertheless, French municipalities have a lower share on the overall tax burden (difference between the line and each dot) than their German counterparts. However, after the 2000 drop in the corporate income tax in Germany, a French municipality could compete with a German one, even when the additional part of the tax burden has to be much smaller.

[Table 1 about here] 
Table 1 shows summary statistics for the effective tax rates and the additional vertical tax burden in both countries. We are taking the logs of all tax variables in our empirical estimation. $^{9}$

\subsection{Socio-economic Data}

Socio-economic variables are introduced to control for different spending needs or preferences for public goods in the local jurisdictions. We include variables that reflect the age distribution as well as the population density and unemployment rate.

[Table 2 about here]

The municipalities in our sample are different in terms of population size. In both countries the share of small jurisdictions is quite substantial, while only a handful of large cities (namely Strasbourg, Freiburg, Baden-Baden) is included. Table 2 presents the summary statistics for our control variables. On average French municipalities are denser than the German ones, which is, given the structure of local governments in both countries, not surprising. The demographic characteristics in both countries are slightly different. Generally speaking, the region in France is populated by younger inhabitants. Since the age structure might reflect preferences over public expenditures, these two characteristics of the population are likely to have an impact on tax rates. For example, the working population is more likely to be in favor of a tax policy oriented to create a good business environment than the older population, whose demand for public goods might be higher. The younger generation is also important, since parents would like to send their children to kindergarten. These kinds of expenditures are imposed at the local level in both countries. We include the unemployment rate since local authorities have certain obligations to unemployed people, such as covering housing-costs in Germany. In addition, the number of unemployed people could be a proxy for the cyclical stance. Furthermore, the log of regional GDP is, one period lagged, included. This controls for the economic conditions and the fact that tax rates usually react one period later to economic outcomes.

\section{Results}

This section discusses the results from our empirical analysis. We focus in what follows on one specific set of results, namely those obtained from the small distance sample with weights constructed by a criterion that regards the six nearest municipalities as neighbors.

\footnotetext{
${ }^{9}$ Summary statistics presented here are for the large sample which included all elements in the $30 \mathrm{~km}$ distance-band to the Rhine.
} 
All further results are reported in full length in B, but our main result remains unchanged in all estimated models.

Table 3 shows the results of instrumental variables estimations according to equation 7. We instrument the endogenous spatial lags with all regressors plus their spatial lags, beside the neighbor's tax rate. In that case, we use one time lagged values as an additional instrument. Moreover, the spatial lags of the demographic variables are excluded from the set of instruments since we cannot reject correlation with the residuals. The computed standard errors are robust to heteroskedasticity and serial correlation (HAC).

[Table 2 about here]

The first estimation (1) presents results from a model that neglects the spatial variables. We will first discuss the impact of the exogenous variables. The age structure matters in both countries. Compared to the group of inhabitants between 15 and 65, a larger share of young people decreases the tax rate. This might be due to the fact that, although communities have to provide services to this group, their parents are in favor of business friendly politics since they are most likely in working age. The impact of the share of the older population is distinct for France and Germany. More older people increase the tax in Germany, while it decreases local taxes in France. Thus, German municipalities might need to generate more revenues to fulfill the preferences of the aged. Both countries try to counteract unemployment by lowering their tax rates in order to establish an attractive environment for business activities. Unlike in Germany, the French local taxes are also on average higher in more densely populated and richer regions. The positive sign on the vertical component suggests at first glance that local taxes act in concert with those on other levels.

We turn now to the discussion of the spatial relationship. The bottommost part of Table 3 shows two Moran I statistics (Moran, 1950), for each country respectively. These statistics indicate that spatial autocorrelation is at present in both countries, but stronger in France. The data generating process in spatial models could either follow a spatial autoregressive model or a spatial error model, where spatial dependence arises only in the disturbances (see LeSage and Pace (2009) for a detailed discussion of spatial modeling). Hence, we have to assure that our spatial lag specification according to equation 6 is the proper one. We use the Lagrange Multiplier test introduced by Anselin et al. (2008) for spatial error correlation and a spatially lagged dependent variable, which is robust against the alternative form, respectively. The p-values of these tests indicate that the spatial error model can be rejected, whereas the spatial lag model according to our specification is accepted.

Model (2) includes only the spatial lag variables, $\rho_{1}$ for interactions among German municipalities, $\rho_{2}$ for interactions between French jurisdictions, and $\rho_{3}$ for cross-border 
interactions. As expected after the results of the previous tests, the within-country interactions are significant on either side of the border. The non-significance of $\rho_{3}$ shows that interactions across the border do not take place. We include the other covariates successively in models (3) to (7) and estimate the full model in (8). The Hansen-J test indicates that the orthogonality of the set of instruments with respect to the residuals cannot be rejected in any model. Furthermore, the Difference-in-Hansen test on the time lags as additional instruments does not reject their validity.

Most exogenous variables, beside the demographic structure, lose their significance when spatial lags are included. The last estimation in column (8), however, shows that the tax rates within the two countries are correlated with the tax rates chosen by their neighboring jurisdictions. The significant coefficients $\rho_{1}$ and $\rho_{2}$ confirm that local jurisdictions within a given country interact over their tax rates. This interactions turn out to be stronger in France, relative to Germany. This is in line with the results of previous studies on German and French data. However, local domestic tax decisions are not related to those decisions undertaken on the other side of the border since $\rho_{3}$ is never found to be significantly different from zero. ${ }^{10}$

Table 5 shows results from the dynamic panel data regression according to model 8 to corroborate our results. ${ }^{11}$ We use all covariates as instruments as before, excluding a trend and squared trend variable. We use the second and third lag of the dependent variable in order to deal with lagged dependent endogeneity. Our coefficient of main interest $\rho_{3}$ on the interactions across the border is again not different from zero at any conventional level of significance.

\section{[Table 5 about here]}

The Hansen-J test p-value is around 0.5 and A/B test for $\mathrm{AR}(2)$ as well as for $\mathrm{AR}(1)$ reveals that autocorrelation is treated in the right way. We use 81 instruments, an acceptable number compared to the number of cross-sections in these estimations. This ensures that the Hansen test is not weakened by the proliferation of instruments. Both other spatially decomposed variables targeting internal competition are significant and positive, confirming the static results. ${ }^{12}$ Thus, our result of absent cross-border interactions is robust to a dynamic specification of the model.

A related question is whether the border or a gap in infrastructure is responsible for this result. The use of adjacent municipalities as neighbors, independent of the ways

\footnotetext{
${ }^{10} \mathrm{As}$ an additional proof to underpin this result, separate models for both countries were estimated with maximum likelihood methods. We analyzed the spatial correlation between the regression leavings (residuals and estimated fixed effects) in a second step for various combinations of spatial weights. As the results never indicate any relationship across the border, results are not reported here.

${ }^{11}$ We only present the coefficients of main interest. The full set of results from this estimation is given in B.2

${ }^{12}$ The point estimates are not restricted to be lower than one since each individual part of the weighting matrix is non-standardized.
} 
how to reach them, suggest that direct information spill-over could be excluded as the underlying reason as long as the results are non-significant. When taxes are set in order to attract, or at least not to lose capital, municipalities which are easy to reach are the more relevant competitors. We compute weights based on distance to analyze this question. We distinguish between weights where the pure air-line distance is used from another set of weights where the Rhine, and hence the border, could be only crossed where infrastructure allows that. In other words, the measure of the distance takes into account that a bridge or a ferry has to be crossed to commute from France to Germany and vice verse.

[Table 6 about here]

Columns (1) and (3) show the pure distance results, according to equation 7, while the infrastructure is taken into account in columns (2) and (4). The first two estimations cut-off distance after 15 kilometers, while the last two do so after 30. Although the results in table 6 do not indicate differences between both alternatives, we can exclude any explanation for possible interactions. Since results of the cross-border term are insignificant in the infrastructure specification, domestic tax rates do not respond at all to those of potential nearby competitors for capital.

\section{Conclusion}

The differentiation between levels of government in the empirical literature on fiscal interactions created a gap, which our aim is to fill. It is now well documented that taxation decisions on the national level depend on decisions taken in other countries on the same level. The same is true for sub-national governments within the borderline of a specific state. Whether domestic local governments act in a similar manner with their foreign counterparts, however, is an open question.

The aim of this paper was to tackle this question empirically. The European Union with the common internal market offers a convenient environment, because legal barriers to the free movement of capital were abolished. The Franco-German context is of particular interest, since revenues from business taxation are an important element of local governments' budgets and have an intense impact on the after-tax profits of firms. Local jurisdictions in the border area, from which we construct our sample, could thus try to increase their tax base by offering good tax conditions. This could be either done relative to other domestic, relative to other foreign, or relative to any other jurisdiction.

Our results do not confirm that a domestic municipality interacts with a foreign one. Although we apply a variety of definitions about neighborhood, significant interaction 
terms could never be found. Albeit this is true in the local-international context, interactions take place domestically in both countries. This finding is consistent with the view that local jurisdictions regard only their domestic counterparts as relevant, taking an earlier choice over the country as given. Overall, we find strong evidence for a border effect in local tax setting.

An intuitive explanation for our result is that costs connected with cross-border competition are comparatively high. Other national characteristics, beside pure tax elements, might be more important for the decision where to settle down for doing business. In particular, the institutional and cultural framework of a different country, and a different language, might determine this outcome, rather than a small differential in tax rates. Once this decision is taken, the question in which specific region the investment should take place, remains open. Thus, local governments try to avoid being unattractive only relative to their domestic neighbors, what creates the border effect we have found. Our result can also be interpreted as an indirect test for regional mobility of capital, which does not seem to be very mobile across the Rhine.

Moreover, taxes are always set by politicians. Their costs of comparing the domestic tax code with the foreign one are also higher than in a pure within-country context. The different tax base can create a particular problem for local politicians in order to evaluate their position relative to foreign municipalities.

Even though we find no empirical evidence for local interactions across national borders and a strong border effect, this calls for further theoretical work analyzing under which conditions interactions would be likely to occur. The variety in sub-national taxation systems, languages and other characteristics in Europe would also allow for further empirical research in different directions. Future work could concentrate on regions, where some barriers are absent (for instance, language in the German-Austrian context) or when the mobility of capital is affected (accession to the European Union). The further understanding of the border effect in a borderless Europe seems to be an interesting question.

\section{References}

Allers, M., Elhorst, J. P. 2005. Tax mimicking and yardstick competition among local governments in the netherlands. International Tax and Public Finance, 12 (4), 493-513.

Anselin, L. 1988. Spatial Econometrics: Methods and Models (Studies in Operational Regional Science). Springer.

Anselin, L., Gallo, J. L., Jayet, H. 2008. Spatial panel econometrics. In The Economet- 
rics of Panel Data, 46 of Advanced Studies in Theoretical and Applied Econometrics, Springer Berlin Heidelberg, 625-660.

Arellano, M., Bond, S. 1991. Some tests of specification for panel data: Monte carlo evidence and an application to employment equations. Review of Economic Studies, 58 (2), 277-97.

Besley, T., Case, A. 1995. Incumbent behavior: Vote-seeking, tax-setting, and yardstick competition. American Economic Review, 85 (1), 25-45.

Bordignon, M., Cerniglia, F., Revelli, F. 2003. In search of yardstick competition: a spatial analysis of italian municipality property tax setting. Journal of Urban Economics, 54 (2), 199-217.

Brett, C., Pinkse, J. 2000. The determinants of municipal tax rates in british columbia. Canadian Journal of Economics, 33 (3), 695-714.

Brueckner, J. K. 2003. Strategic interaction among governments: An overview of empirical studies. International Regional Science Review, 2, 175-188.

Brueckner, J. K., Saavedra, L. A. 2001. Do local governments engage in strategic propertytax competition? National Tax Journal, 54 (2), 203-230.

Buettner, T. 2001. Local business taxation and competition for capital: the choice of the tax rate. Regional Science and Urban Economics, 31 (2-3), 215-245.

Buettner, T. 2003. Tax base effects and fiscal externalities of local capital taxation: evidence from a panel of german jurisdictions. Journal of Urban Economics, 54 (1), $110-128$.

Cassette, A., Paty, S. 2008. Tax competition among eastern and western european countries: With whom do countries compete? Economic Systems, 32 (4), 307-325.

Charlot, S., Paty, S. 2007. Market access effect and local tax setting: evidence from french panel data. Journal of Economic Geography, 7 (3), 247-263.

Charlot, S., Paty, S. 2010. Do agglomeration forces strengthen tax interactions? Urban Studies, 47 (13).

Commission, E. 2001. Company taxation in the internal market. (0005).

Devereux, M. P., Griffith, R. 2003. Evaluating tax policy for location decisions. International Tax and Public Finance, 10 (2), 107-26. 
Devereux, M. P., Elschner, C., Endres, D., Heckemeyer, J. H., Overesch, M., Schreiber, U., Spengel, C. 2008. Effective levels of company taxation within an enlarged eu. Working Paper (22).

Devereux, M. P., Lockwood, B., Redoano, M. 2008. Do countries compete over corporate tax rates? Journal of Public Economics, 92 (5-6), 1210 - 1235.

Dubois, E., Leprince, M., Paty, S. 2007. The effects of politics on local tax setting: Evidence from france. Urban Stud, 44 (8), 1603-1618.

Edmark, K., Ågren, H. 2008. Identifying strategic interactions in swedish local income tax policies. Journal of Urban Economics, 63 (3), 849 - 857.

Feld, L. P., Reulier, E. 2009. Strategic tax competition in switzerland: Evidence from a panel of the swiss cantons. German Economic Review, 1 (10(1)), 91-114.

Feld, L. P., Rocaboy, J.-M. J. Y. 2003. Tax mimicking among regional jurisdiction. In A. Marciano, J. Josselin eds. From economic to legal competition. New perspectives on law and institutions in Europe, Edward Elgar, London, 105-119.

Gérard, M., Jayet, H., Paty, S. 2010. Tax interactions among belgian municipalities: Do interregional differences matter? Regional Science and Urban Economics, 40 (5), 336-342. Advances In Spatial Econometrics.

Heyndels, B., Vuchelen, J. 1998. Tax mimicking among belgian municipalities. National Tax Journal, LI (1), 89-102.

Jayet, H., Paty, S., Pentel, A. 2002. Existe-t-il des interactions fiscales stratégiques entre les collectivités locales. Economie et Pr'evisio, 154, 95-105.

Kelejian, H. H., Prucha, I. R. 1998. A generalized spatial two-stage least squares procedure for estimating a spatial autoregressive model with autoregressive disturbances. The Journal of Real Estate Finance and Economics, 17 (1), 99-121.

Kelejian, H. H., Robinson, D. P. 1993. A suggested method of estimation for spatial interdependent models with autocorrelated errors, and an application to a county expenditure model. Papers in Regional Science, 72, 297-312. 10.1007/BF01434278.

Kukenova, M., Monteiro, J.-A. 2009. Spatial dynamic panel model and system gmm: A monte carlo investigation. mpra paper, University Library of Munich, Germany.

Leprince, M., Madiès, T., Paty, S. 2007. Business tax interactions among local governments: An empirical analysis of the french case. Journal of Regional Science, 47 (3), 603-621. 
LeSage, J., Pace, R. K. 2009. Introduction to Spatial Econometrics (Statistics: a Series of Textbooks and Monographs). Chapman \& Hall/CRC.

Lockwood, B. 2004. Competition in unit vs. ad valorem taxes. International Tax and Public Finance, 11 (6), 763-772.

Moran, P. A. P. 1950. Notes on continuous stochastic phenomena. Biometrika, 37 (1/2), $17-23$.

Newey, W. K., West, K. D. 1987. A simple, positive semi-definite, heteroskedasticity and autocorrelation consistent covariance matrix. Econometrica, 55 (3), 703-708.

OECD 1991. Taxing profits in a global economy : domestic and international issues. Organisation for Economic Co-operation and Development.

Redoano, M. 2007. Fiscal interactions among european countries. does the eu matter? CESifo Working Paper Series 1952, CESifo.

Revelli, F. 2001. Spatial patterns in local taxation: Tax mimicking or error mimicking? Applied Economics, 33 (9), 1101-07.

Revelli, F. 2006. Spatial interactions among governments. In E. Ahmad, G. Brosio eds. Handbook of Fiscal Federalism, Chap. 4, 106-130.

Roodman, D. 2009. A note on the theme of too many instruments. Oxford Bulletin of Economics and Statistics, 71 (1), 135-158.

Scheffler, W. 2002. Besteuerung von Unternehmen I. Ertrag-, Substanz- und Verkehrsteuern. UTB Uni-Taschenbücher Verlag.

Solé-Ollé, A. 2003. Electoral accountability and tax mimicking: the effects of electoral margins, coalition government, and ideology. European Journal of Political Economy, 19 (4), 685-713.

Tobler, W. R. 1970. A computer movie simulating urban growth in the detroit region. Economic Geography, 46, pp. 234-240.

Wilson, J. D. 1999. Theories of tax competition. National Tax Journal, 2, 269-304.

Zodrow, G. R., Mieszkowski, P. 1986. Pigou, tiebout, property taxation, and the underprovision of local public goods. Journal of Urban Economics, 19 (3), 356-370. 


\section{Graphs and Tables}

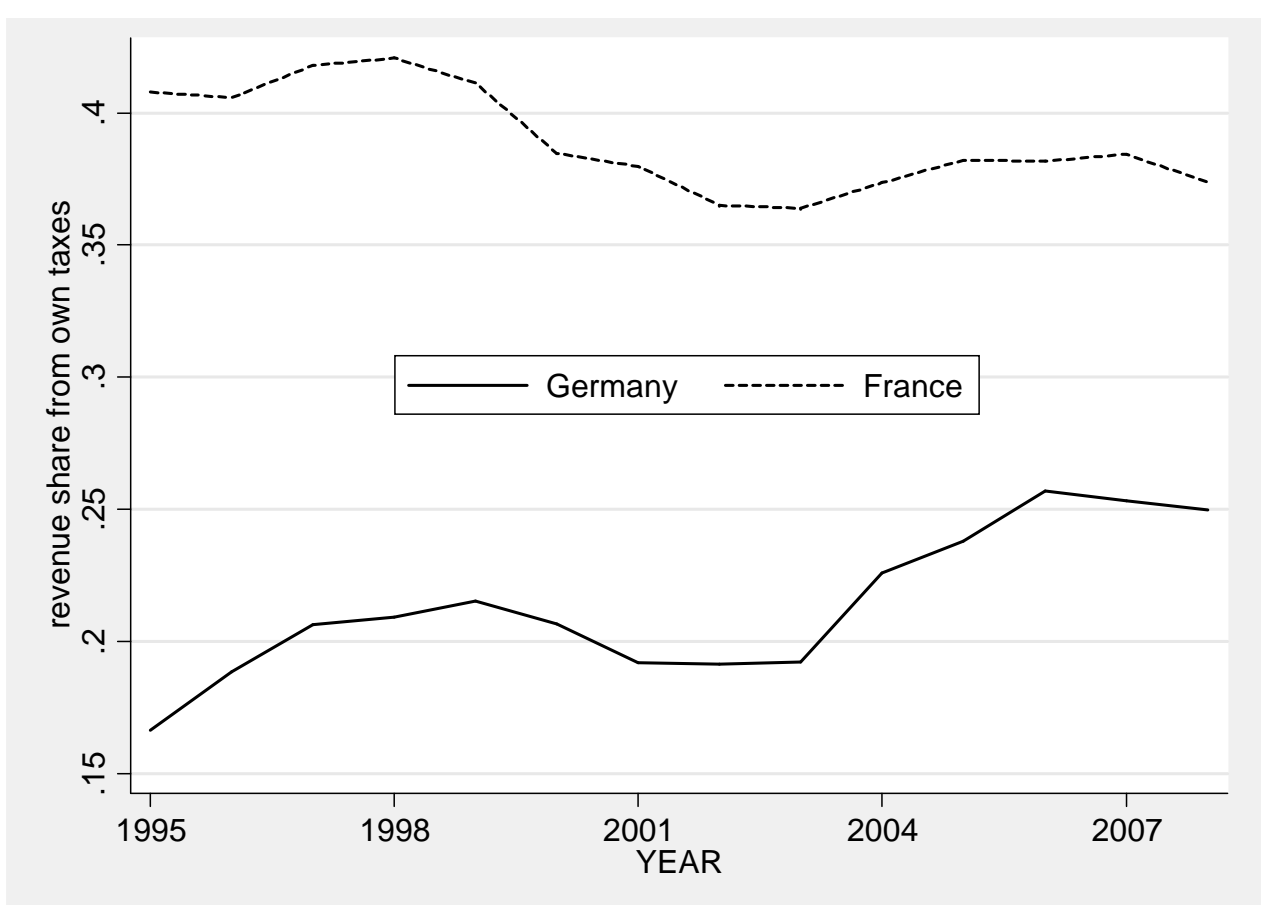

Share of revenues generated by taxes, where the tax rate is decided at the sub-national level.

Figure 1: Revenues from own-source taxation

\begin{tabular}{lllllll}
\hline Variable & & Mean & Std. Dev. & Min & Max & Observations \\
\hline Germany & & & & & & \\
\hline local eatr & overall & 0.136 & 0.006 & 0.121 & 0.159 & $\mathrm{~N}=1320$ \\
& between & & 0.005 & 0.123 & 0.158 & $\mathrm{n}=165$ \\
& within & & 0.002 & 0.119 & 0.150 & $\mathrm{~T}=8$ \\
vertical eatr & overall & 0.241 & 0.017 & 0.231 & 0.285 & \\
& between & & 0.000 & 0.241 & 0.241 & \\
& within & & 0.017 & 0.231 & 0.285 & \\
\hline \multirow{2}{*}{ France } & & & & & & \\
\hline \multirow{2}{*}{ local eatr } & overall & \multirow{2}{*}{0.030} & 0.009 & 0.007 & 0.060 & $\mathrm{~N}=3496$ \\
& between & & 0.009 & 0.011 & 0.058 & $\mathrm{n}=437$ \\
& within & & 0.002 & 0.013 & 0.051 & $\mathrm{~T}=8$ \\
vertical eatr & overall & \multirow{2}{*}{0.316} & 0.007 & 0.308 & 0.333 & \\
& between & & 0.001 & 0.315 & 0.317 & \\
& within & & 0.007 & 0.309 & 0.332 & \\
\hline
\end{tabular}

Table 1: Summary statistics: tax variables 


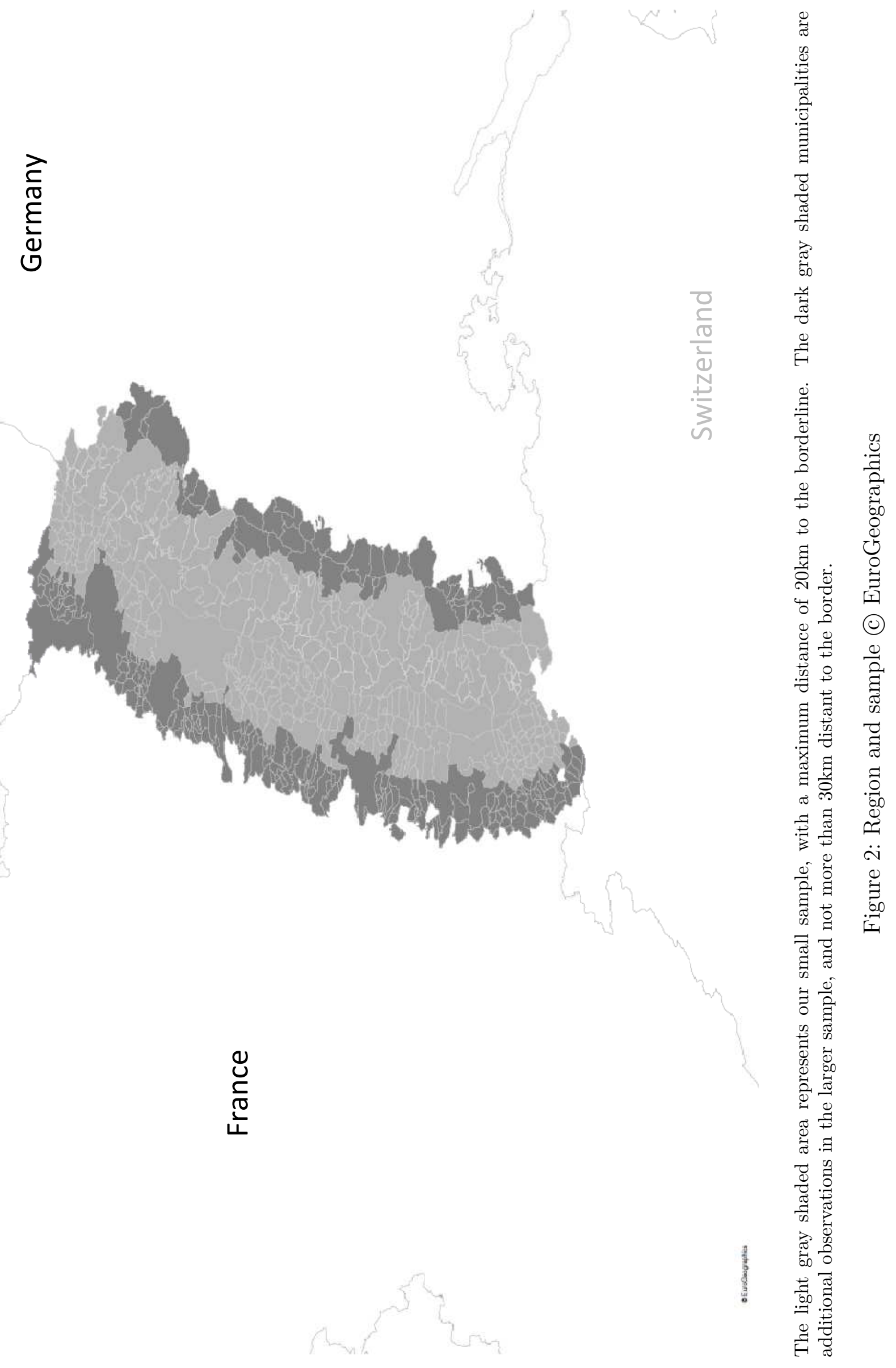




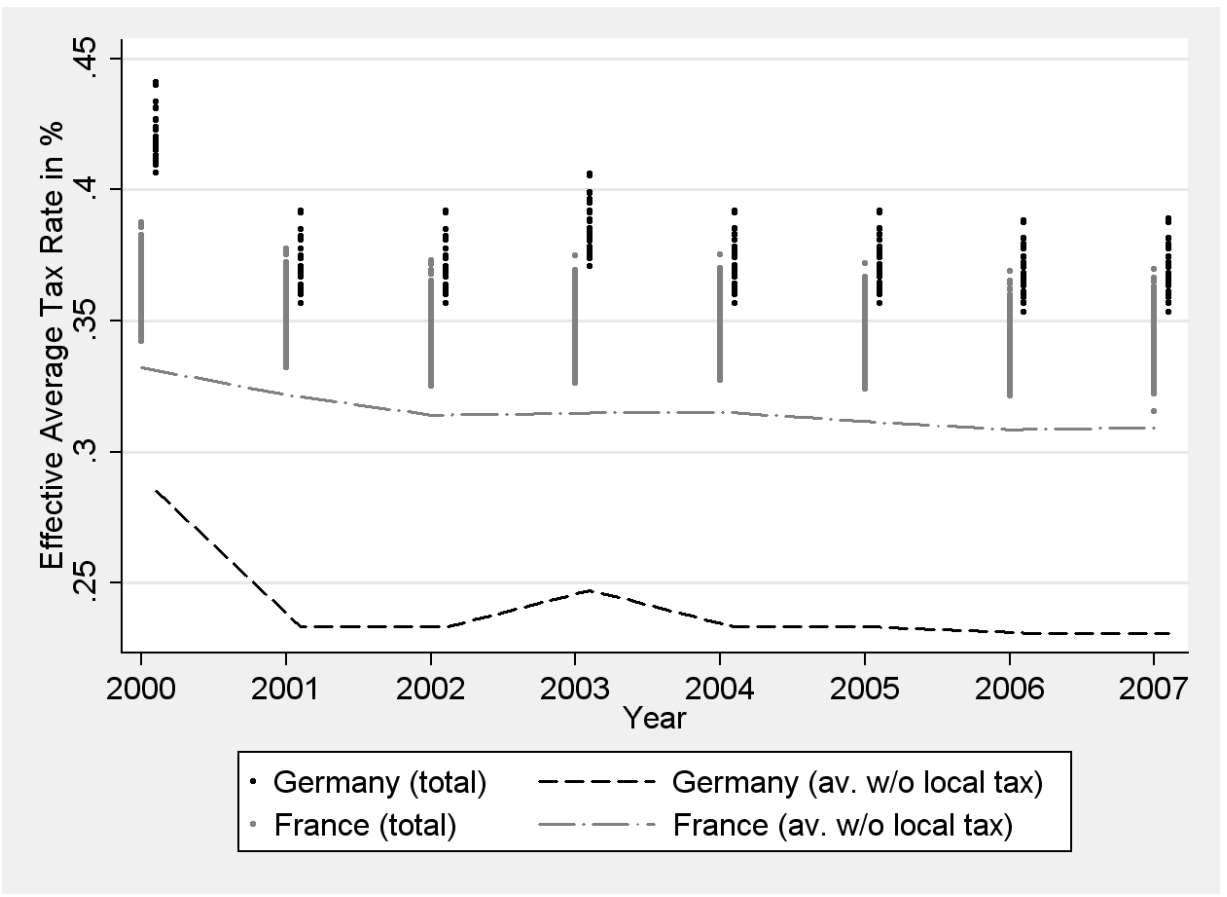

Decomposition of the EATR. Each dot represents the overall tax burden in a specific municipality. Lines represent the tax burden due to higher than local level governments. The distance from zero to the respective line is the measure of the vertical tax burden in our estimations. The difference between the line and each dot is the additional local tax burden, which we use in logs as our dependent variable.

Figure 3: Effective average tax rates 2000-2007 


\begin{tabular}{|c|c|c|c|c|c|c|}
\hline Variable & & Mean & Std. Dev. & Min & Max & Observations \\
\hline \multicolumn{7}{|l|}{ Germany } \\
\hline \multirow[t]{3}{*}{ pp15 } & overall & 16.894 & 2.004 & 6.154 & 23.958 & $\mathrm{~N}=1320$ \\
\hline & between & & 1.751 & 9.617 & 20.839 & $\mathrm{n}=165$ \\
\hline & within & & 0.984 & 10.650 & 20.046 & $\mathrm{~T}=8$ \\
\hline \multirow[t]{3}{*}{ pp65 } & overall & 16.996 & 3.088 & 7.612 & 28.429 & \\
\hline & between & & 2.833 & 8.547 & 26.987 & \\
\hline & within & & 1.244 & 13.057 & 20.843 & \\
\hline \multirow[t]{3}{*}{ unempl } & overall & 3.381 & 1.148 & 0.000 & 9.187 & \\
\hline & between & & 1.003 & 0.000 & 7.443 & \\
\hline & within & & 0.563 & 1.439 & 5.810 & \\
\hline \multirow[t]{3}{*}{ dens } & overall & 294.219 & 254.017 & 16.931 & 1698.551 & \\
\hline & between & & 254.611 & 18.034 & 1671.332 & \\
\hline & within & & 6.490 & 243.381 & 336.992 & \\
\hline \multirow[t]{3}{*}{$\log \operatorname{gdp}(t-1)$} & overall & 10.063 & 0.178 & 9.732 & 10.632 & \\
\hline & between & & 0.162 & 9.856 & 10.505 & \\
\hline & within & & 0.075 & 9.914 & 10.224 & \\
\hline \multicolumn{7}{|l|}{ France } \\
\hline \multirow[t]{3}{*}{ pp15 } & overall & 19.450 & 2.231 & 10.369 & 29.167 & $\mathrm{~N}=3496$ \\
\hline & between & & 2.045 & 14.192 & 25.799 & $\mathrm{n}=437$ \\
\hline & within & & 0.896 & 14.617 & 24.356 & $\mathrm{~T}=8$ \\
\hline \multirow[t]{3}{*}{ pp65 } & overall & 13.819 & 2.963 & 4.974 & 26.007 & \\
\hline & between & & 2.849 & 5.661 & 23.503 & \\
\hline & within & & 0.826 & 9.726 & 17.962 & \\
\hline \multirow[t]{3}{*}{ unempl } & overall & 5.854 & 2.161 & 0.000 & 15.791 & \\
\hline & between & & 1.962 & 0.985 & 13.955 & \\
\hline & within & & 0.909 & 0.566 & 10.083 & \\
\hline \multirow[t]{3}{*}{ dens } & overall & 177.042 & 219.673 & 19.415 & 2238.687 & \\
\hline & between & & 219.775 & 21.750 & 2184.338 & \\
\hline & within & & 7.212 & 122.774 & 231.391 & \\
\hline \multirow[t]{3}{*}{$\log \operatorname{gdp}(t-1)$} & overall & 10.055 & 0.102 & 9.862 & 10.241 & \\
\hline & between & & 0.048 & 10.003 & 10.100 & \\
\hline & within & & 0.090 & 9.906 & 10.205 & \\
\hline
\end{tabular}

Table 2: Summary statistics: control variables 


\begin{tabular}{|c|c|c|c|c|c|c|c|c|}
\hline & (1) & $(2)$ & $(3)$ & (4) & (5) & (6) & (7) & (8) \\
\hline de_pp15 & $\begin{array}{c}-0.003^{*} \\
(0.002)\end{array}$ & & $\begin{array}{l}-0.003 \\
(0.002)\end{array}$ & & & & & $\begin{array}{c}-0.003^{*} \\
(0.002)\end{array}$ \\
\hline de_pp65 & $\begin{array}{l}0.003^{*} \\
(0.002)\end{array}$ & & $\begin{array}{l}-0.003 \\
(0.002)\end{array}$ & & & & & $\begin{array}{l}-0.001 \\
(0.002)\end{array}$ \\
\hline de_unempl & $\begin{array}{c}-0.012^{* * *} \\
(0.002)\end{array}$ & & & $\begin{array}{l}-0.002 \\
(0.002)\end{array}$ & & & & $\begin{array}{l}-0.002 \\
(0.002)\end{array}$ \\
\hline de_dens & $\begin{array}{l}-0.000 \\
(0.000)\end{array}$ & & & & $\begin{array}{c}-0.000^{*} \\
(0.000)\end{array}$ & & & $\begin{array}{l}-0.000 \\
(0.000)\end{array}$ \\
\hline de_log_reg_gdp & $\begin{array}{l}-0.006 \\
(0.043)\end{array}$ & & & & & $\begin{array}{c}0.017 \\
(0.042)\end{array}$ & & $\begin{array}{l}-0.012 \\
(0.041)\end{array}$ \\
\hline fr_pp15 & $\begin{array}{c}-0.006^{*} \\
(0.003)\end{array}$ & & $\begin{array}{c}-0.004^{*} \\
(0.002)\end{array}$ & & & & & $\begin{array}{c}-0.004^{*} \\
(0.002)\end{array}$ \\
\hline fr_pp65 & $\begin{array}{c}-0.004^{*} \\
(0.002)\end{array}$ & & $\begin{array}{c}-0.006^{* * *} \\
(0.002)\end{array}$ & & & & & $\begin{array}{c}-0.006^{* * *} \\
(0.002)\end{array}$ \\
\hline fr_unempl & $\begin{array}{c}-0.007 * * * \\
(0.003)\end{array}$ & & & $\begin{array}{l}-0.000 \\
(0.002)\end{array}$ & & & & $\begin{array}{l}-0.001 \\
(0.002)\end{array}$ \\
\hline fr_dens & $\begin{array}{c}0.002^{* *} \\
(0.001)\end{array}$ & & & & $\begin{array}{c}0.000 \\
(0.000)\end{array}$ & & & $\begin{array}{l}-0.000 \\
(0.000)\end{array}$ \\
\hline fr_log_reg_gdp & $\begin{array}{c}0.354^{* * *} \\
(0.060)\end{array}$ & & & & & $\begin{array}{c}0.025 \\
(0.058)\end{array}$ & & $\begin{array}{c}0.044 \\
(0.065)\end{array}$ \\
\hline vertical_eatr & $\begin{array}{c}0.117^{* *} \\
(0.046)\end{array}$ & & & & & & $\begin{array}{l}-0.040 \\
(0.055)\end{array}$ & $\begin{array}{l}-0.008 \\
(0.050)\end{array}$ \\
\hline$\rho_{1}$ & & $\begin{array}{c}0.441 * * \\
(0.191)\end{array}$ & $\begin{array}{c}0.512^{* * *} \\
(0.161)\end{array}$ & $\begin{array}{c}0.406^{* *} \\
(0.199)\end{array}$ & $\begin{array}{c}0.496^{* * *} \\
(0.172)\end{array}$ & $\begin{array}{c}0.488^{* * * *} \\
(0.156)\end{array}$ & $\begin{array}{c}0.435^{* *} \\
(0.192)\end{array}$ & $\begin{array}{c}0.530^{* * *} \\
(0.163)\end{array}$ \\
\hline$\rho_{2}$ & & $\begin{array}{c}0.922^{* * *} \\
(0.095)\end{array}$ & $\begin{array}{c}0.937^{* * *} \\
(0.117)\end{array}$ & $\begin{array}{c}0.915^{* * *} \\
(0.096)\end{array}$ & $\begin{array}{c}0.908^{* * *} \\
(0.101)\end{array}$ & $\begin{array}{c}0.921^{* * *} \\
(0.124)\end{array}$ & $\begin{array}{c}0.917^{* * * *} \\
(0.097)\end{array}$ & $\begin{array}{c}0.911^{* * *} \\
(0.132)\end{array}$ \\
\hline$\rho_{3}$ & & $\begin{array}{c}0.006 \\
(0.115)\end{array}$ & $\begin{array}{l}-0.024 \\
(0.090)\end{array}$ & $\begin{array}{c}0.017 \\
(0.113)\end{array}$ & $\begin{array}{c}0.021 \\
(0.108)\end{array}$ & $\begin{array}{l}-0.105 \\
(0.099)\end{array}$ & $\begin{array}{c}0.050 \\
(0.124)\end{array}$ & $\begin{array}{c}0.024 \\
(0.123)\end{array}$ \\
\hline R-squared & 0.328 & 0.404 & 0.407 & 0.405 & 0.405 & 0.404 & 0.404 & 0.409 \\
\hline Hansen J & . & 3.280 & 3.397 & 2.747 & 3.655 & 3.520 & 3.485 & 3.382 \\
\hline Hansen J (p-value) & . & 0.350 & 0.494 & 0.601 & 0.455 & 0.475 & 0.480 & 0.496 \\
\hline Diff. Hansen Lags & . & . & . & . & . & . & . & 2.579 \\
\hline $\mathrm{p}$-value & . & . & . & . & . & . & . & 0.461 \\
\hline Moran's I DE & $0.08^{* * *}$ & . & . & . & . & . & . & . \\
\hline Moran's I FR & $0.31 * * *$ & . & . & . & . & . & . & . \\
\hline LM lag (p-value) & 0.00 & . & . & . & . & . & . & . \\
\hline LM error (p-value) & 0.99 & . & . & . & . & . & . & . \\
\hline \multicolumn{9}{|c|}{$\begin{array}{l}\text { Robust standard errors in parentheses, } \mathrm{n}=347, \mathrm{~T}=8 \\
\text { tax variables in logs, }{ }^{* * *} \mathrm{p}<0.01,{ }^{*} \mathrm{p}<0.05,{ }^{*} \mathrm{p}<0.1\end{array}$} \\
\hline
\end{tabular}

Table 3: Results with $6 \mathrm{NN}$ weights used, 20KM distance 


\begin{tabular}{|c|c|c|c|c|c|c|c|c|}
\hline & (1) & $(2)$ & (3) & (4) & (5) & $(6)$ & (7) & (8) \\
\hline de_pp15 & $\begin{array}{c}-0.002^{*} \\
(0.001)\end{array}$ & & $\begin{array}{l}-0.002 \\
(0.001)\end{array}$ & & & & & $\begin{array}{c}-0.002 \\
(0.001)\end{array}$ \\
\hline de_pp65 & $\begin{array}{c}0.001 \\
(0.001)\end{array}$ & & $\begin{array}{l}-0.000 \\
(0.002)\end{array}$ & & & & & $\begin{array}{c}0.000 \\
(0.001)\end{array}$ \\
\hline de_unempl & $\begin{array}{c}-0.011^{* * *} \\
(0.001)\end{array}$ & & & $\begin{array}{c}-0.003^{*} \\
(0.001)\end{array}$ & & & & $\begin{array}{l}-0.003^{*} \\
(0.001)\end{array}$ \\
\hline de_dens & $\begin{array}{c}-0.000^{* *} \\
(0.000)\end{array}$ & & & & $\begin{array}{c}-0.000^{* *} \\
(0.000)\end{array}$ & & & $\begin{array}{c}-0.000 * * \\
(0.000)\end{array}$ \\
\hline de_log_reg_gdp & $\begin{array}{l}-0.029 \\
(0.043)\end{array}$ & & & & & $\begin{array}{c}0.000 \\
(0.042)\end{array}$ & & $\begin{array}{l}-0.020 \\
(0.041)\end{array}$ \\
\hline fr_pp15 & $\begin{array}{c}-0.005^{* *} \\
(0.002)\end{array}$ & & $\begin{array}{c}-0.003^{* *} \\
(0.001)\end{array}$ & & & & & $\begin{array}{c}-0.003^{* *} \\
(0.001)\end{array}$ \\
\hline fr_pp65 & $\begin{array}{l}-0.001 \\
(0.002)\end{array}$ & & $\begin{array}{c}-0.002 \\
(0.002)\end{array}$ & & & & & $\begin{array}{l}-0.003 \\
(0.002)\end{array}$ \\
\hline fr_unempl & $\begin{array}{l}-0.002 \\
(0.002)\end{array}$ & & & $\begin{array}{l}-0.000 \\
(0.001)\end{array}$ & & & & $\begin{array}{l}-0.000 \\
(0.001)\end{array}$ \\
\hline fr_dens & $\begin{array}{c}0.001^{* *} \\
(0.000)\end{array}$ & & & & $\begin{array}{l}-0.000 \\
(0.000)\end{array}$ & & & $\begin{array}{c}0.000 \\
(0.000)\end{array}$ \\
\hline fr_log_reg_gdp & $\begin{array}{c}0.266^{* * *} \\
(0.049)\end{array}$ & & & & & $\begin{array}{c}0.008 \\
(0.051)\end{array}$ & & $\begin{array}{c}0.004 \\
(0.053)\end{array}$ \\
\hline vertical_eatr & $\begin{array}{c}0.108^{* * *} \\
(0.030)\end{array}$ & & & & & & $\begin{array}{l}-0.051 \\
(0.042)\end{array}$ & $\begin{array}{l}-0.026 \\
(0.040)\end{array}$ \\
\hline$\rho_{1}$ & & $\begin{array}{c}0.530^{* * *} * \\
(0.177)\end{array}$ & $\begin{array}{c}0.512^{* * *} \\
(0.127)\end{array}$ & $\begin{array}{c}0.488^{* * *} \\
(0.180)\end{array}$ & $\begin{array}{c}0.554^{* * *} \\
(0.166)\end{array}$ & $\begin{array}{c}0.553^{* * *} \\
(0.138)\end{array}$ & $\begin{array}{c}0.518^{* * *} \\
(0.181)\end{array}$ & $\begin{array}{c}0.503^{* * *} \\
(0.125)\end{array}$ \\
\hline$\rho_{2}$ & & $\begin{array}{c}0.904^{* * *} \\
(0.080)\end{array}$ & $\begin{array}{c}0.913^{* * *} * \\
(0.096)\end{array}$ & $\begin{array}{c}0.897^{* * *} \\
(0.081)\end{array}$ & $\begin{array}{c}0.901^{* * *} \\
(0.084)\end{array}$ & $\begin{array}{c}0.896^{* * *} \\
(0.104)\end{array}$ & $\begin{array}{c}0.897^{* * *} \\
(0.082)\end{array}$ & $\begin{array}{c}0.891^{* * *} \\
(0.107)\end{array}$ \\
\hline$\rho_{3}$ & & $\begin{array}{l}-0.037 \\
(0.102)\end{array}$ & $\begin{array}{l}-0.040 \\
(0.087)\end{array}$ & $\begin{array}{l}-0.036 \\
(0.099)\end{array}$ & $\begin{array}{l}-0.017 \\
(0.097)\end{array}$ & $\begin{array}{c}0.003 \\
(0.105)\end{array}$ & $\begin{array}{c}0.016 \\
(0.117)\end{array}$ & $\begin{array}{c}0.071 \\
(0.126)\end{array}$ \\
\hline R-squared & 0.298 & 0.373 & 0.373 & 0.373 & 0.373 & 0.373 & 0.373 & 0.375 \\
\hline Hansen J & . & 1.410 & 2.018 & 0.943 & 1.887 & 1.754 & 0.683 & 1.534 \\
\hline Hansen J (p-value) & . & 0.842 & 0.733 & 0.918 & 0.757 & 0.781 & 0.953 & 0.821 \\
\hline Diff. Hansen Lags & . & . & . & . & . & . & . & 0.366 \\
\hline $\mathrm{p}$-value & . & . & . & . & . & . & . & 0.947 \\
\hline \multicolumn{9}{|c|}{$\begin{array}{c}\text { Robust standard errors in parentheses, } \mathrm{n}=602, \mathrm{~T}=8 \\
{ }_{* * *} \mathrm{p}<0.01,{ }^{* *} \mathrm{p}<0.05,{ }^{*} \mathrm{p}<0.1\end{array}$} \\
\hline
\end{tabular}

Table 4: Results with 6NN weights used, 30KM distance

\begin{tabular}{lcccc}
\hline & $(1)$ & $(2)$ & $(3)$ & $(4)$ \\
\hline$\rho_{3}$ & 0.016 & 0.023 & -0.023 & -0.297 \\
std. err. & $(0.134)$ & $(0.101)$ & $(0.142)$ & $(0.182)$ \\
A/B test AR $(2)$ & 0.679 & 0.397 & 0.538 & 0.309 \\
Hansen J & 0.501 & 0.934 & 0.544 & 0.582 \\
\hline
\end{tabular}

Robust standard errors in parentheses p-values are reported for tests *** $\mathrm{p}<0.01, * * \mathrm{p}<0.05, * \mathrm{p}<0.1$

\# instruments: $81,20 \mathrm{~km} \mathrm{n}=347,30 \mathrm{~km} \mathrm{n}=602, \mathrm{~T}=8$

Difference-GMM estimations. Model (1) and (3) are based on the $30 \mathrm{~km}$ sample, (2) and (4) on the $20 \mathrm{~km}$ sample. The first two regressions use a weighting scheme on the 8 nearest neighbors, while the last two models are based on 6 nearest neighbors.

Table 5: Dynamic panel data estimation 


\begin{tabular}{|c|c|c|c|c|}
\hline & $\begin{array}{c}(1) \\
\text { DIST15 }\end{array}$ & $\begin{array}{c}(2) \\
\text { INFRA15 }\end{array}$ & $\begin{array}{c}(3) \\
\text { DIST30 }\end{array}$ & $\begin{array}{c}(4) \\
\text { INFRA30 }\end{array}$ \\
\hline$\rho_{1}$ & $\begin{array}{c}0.773^{* * *} \\
(0.213)\end{array}$ & $\begin{array}{c}0.746^{* * *} \\
(0.205)\end{array}$ & $\begin{array}{l}1.162^{* *} \\
(0.487)\end{array}$ & $\begin{array}{l}1.018^{* * * *} \\
(0.391)\end{array}$ \\
\hline$\rho_{2}$ & $\begin{array}{c}1.130^{* * *} \\
(0.145)\end{array}$ & $\begin{array}{c}1.146^{* * *} \\
(0.148)\end{array}$ & $\begin{array}{c}1.509^{* * *} \\
(0.197)\end{array}$ & $\begin{array}{c}1.520^{* * *} \\
(0.200)\end{array}$ \\
\hline$\rho_{3}$ & $\begin{array}{l}-0.013 \\
(0.084)\end{array}$ & $\begin{array}{l}-0.021 \\
(0.068)\end{array}$ & $\begin{array}{l}-0.066 \\
(0.174)\end{array}$ & $\begin{array}{c}-0.091 \\
(0.140)\end{array}$ \\
\hline \multicolumn{5}{|c|}{$\begin{array}{l}\text { Robust standard errors in parentheses, } \mathrm{n}=347, \mathrm{~T}=8 \\
\qquad * * \mathrm{p}<0.01,{ }^{* *} \mathrm{p}<0.05,{ }^{*} \mathrm{p}<0.1\end{array}$} \\
\hline
\end{tabular}

Static regressions. All estimations are based on the $20 \mathrm{~km}$ sample. The first two regressions use a weighting scheme that cuts-off after $15 \mathrm{kms}$, while the last two models cut-off after $30 \mathrm{~km}$. Model (1) and (3) are based on pure air-distances, the weights in model (2) and (4) take the infrastructure into account.

Table 6: Distance based regressions 


\section{A. Local Effective Average Tax Rates}

We compute effective average tax rates according to the method proposed by Devereux and Griffith (2003). This allows us to get comparable measures of the tax burden in the two countries. The effective average tax rate is defined for a given value $p$ as an assumption over the financial return of the investment. The net present value of before tax returns is

$$
R^{*}=-1+\frac{1+\pi}{1+i}[(p+\delta)+(1-\delta)]
$$

In the absence of taxation and $(1+i)=(1+r)(1+\pi)$, we obtain

$$
R^{*}=\frac{p-r}{1+r}
$$

and our calculation of $R$ as the after-tax net present value follows the examples given in Devereux et al. (2008), while we allow for different values of subnational taxes for each jurisdiction.

The EATR is based on the difference between the NPV of the perturbation to the capital stock in the absence and presence of tax, $R^{*}-R$, which is a measure of the total impact of taxation on the investor. This difference is scaled using the NPV of the pre-tax total income stream, net of depreciation,

$$
E A T R=\frac{R^{*}-R}{\frac{p}{(1+r)}}
$$

Table 7 sums up the values of the economic parameters we use in all calculations. We use the same economic parameters for the calculation in all periods and both countries to figure out the evolution of taxation parameters and the differences in the tax systems rather than the development of economic conditions.

Five different types of investment are considered - buildings, financial assets, machinery, intangibles and inventories. These hypothetical investments could be financed through three different sources - retained earnings, debt and new equity. The parametrization follows strictly the previous studies.

Investments in industrial buildings trigger liability to real estate tax in both countries. The tax base is determined by the notional annual rent if the property was let on the open market. However this notional rent is often substantially lower than the market rental value, even if every year the notional rent is multiplied by a factor to reflect the 


\begin{tabular}{llc}
\hline Variable & Symbol & Value in $\%$ \\
\hline True economic depreciation rate of intangibles & $\delta_{I N T}$ & 15.35 \\
True economic depreciation rate of industrial buildings & $\delta_{B U I}$ & 3.1 \\
True economic depreciation rate of machinery & $\delta_{M A C}$ & 17.5 \\
True economic depreciation rate of finacial assets & $\delta_{F I N}$ & 0 \\
True economic depreciation rate of inventories & $\delta_{I N V}$ & 0 \\
\hline Real interest rate & $r$ & 5 \\
Inflation rate & $\pi$ & 2 \\
Pre-tax rate of return for EATR & $p$ & 20 \\
Nominal interest rate $(\%)$ & $i=(1+r)(1+\pi)-1$ & 7.1 \\
\hline
\end{tabular}

Table 7: Economic Parameters

national variation of prices. ${ }^{13}$ In Germany these values relate to the locations' market values in the past. In these cases, Devereux et al. (2008) made assumptions concerning the country-specific relation between the acquisition cost used in the model and the tax value determined by the tax offices. In table 8 , we give the rental value rate $\sigma$ for each type of capital.

\begin{tabular}{|c|c|c|}
\hline$\sigma$ & machinery & buildings \\
\hline France & $16 \%(\mathrm{tp})$ & $8 \%(\mathrm{tp}) \quad 4 \%(\mathrm{tf})$ \\
\hline Germany & & $25 \%(\mathrm{pt})$ \\
\hline
\end{tabular}

Table 8: rental value rate Devereux et al. (2008)

Applying this parametrization, the tax laws related to the local taxes (presented in section 2), and the above described equations, we are able to compute country-specific effective average tax rates for a set of five investment goods (buildings, machinery, inventory, finacial and intangible assets) and three financing opportunities (retained earnings, new equity and debt). We compute weighted effective average tax rates for each municipality. According to OECD (1991) we use the following weights: 55\% retained earnings, $10 \%$ new equity, and 35\% debt. Next, we follow the European Commission 2001 and use equal weights for each asset to calculate municipal-specific averages of the EATR. We obtain the tax rates of the different governmental levels by setting the taxes on other levels equal to zero.

\footnotetext{
${ }^{13}$ In France, the individual values of properties have not been reviewed by tax authorities since 1974 .
} 


\section{B. Additional tables}

The full set of results from the intsrumental variables regressions are presented in this section.

\section{B.1. Full IV-Estimates}

Table 9 presents the estimations over a variation of different weights based on nearest neighbor criterions, ranging from NN4 to NN8 over both sub-samples. The full set of estimations with distance based weights is shown in table 10. This table shows in addition the full results for weights where the infrastructure is taken into account. 


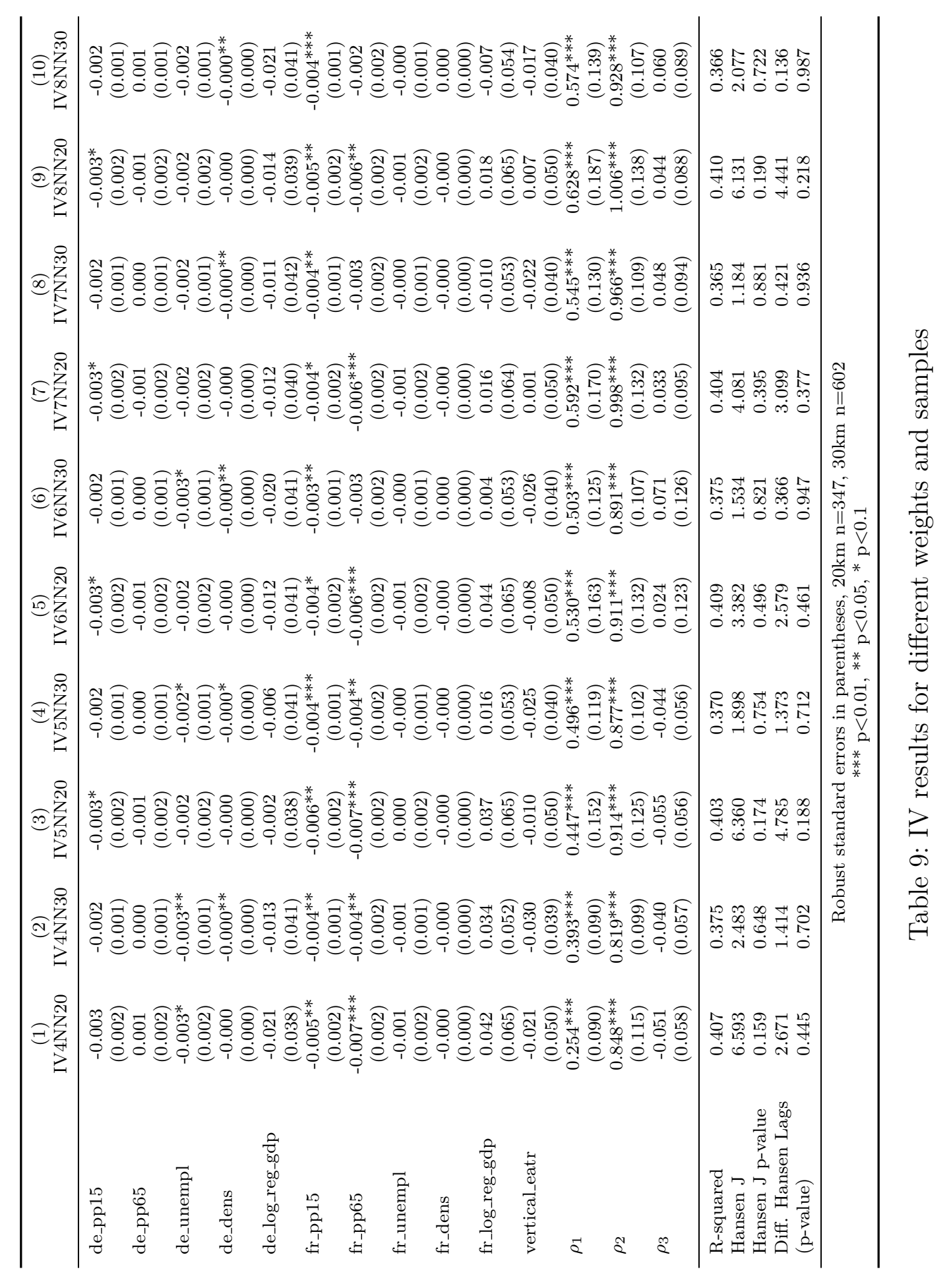




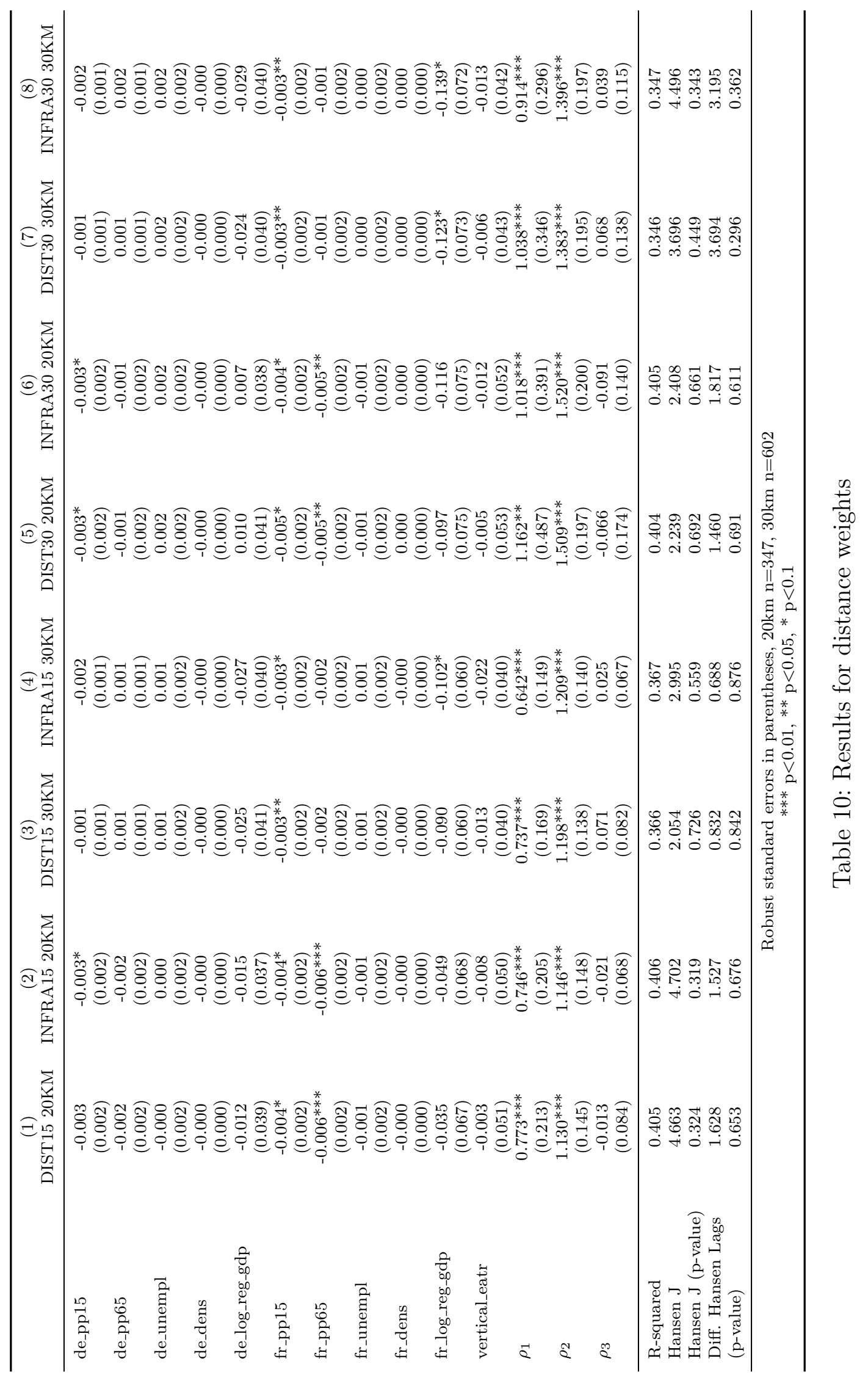


B.2. Full GMM-Estimates

\begin{tabular}{|c|c|c|c|c|}
\hline VARIABLES & $\begin{array}{c}(1) \\
\text { GMM } 8 \mathrm{NN} 30 \mathrm{~km}\end{array}$ & $\begin{array}{c}(2) \\
\text { GMM } 8 \mathrm{NN} 20 \mathrm{~km}\end{array}$ & $\begin{array}{c}(3) \\
\text { GMM } 6 \mathrm{NN} 30 \mathrm{~km}\end{array}$ & $\begin{array}{c}(4) \\
\text { GMM } 6 \mathrm{NN} 20 \mathrm{~km}\end{array}$ \\
\hline \multirow[t]{2}{*}{ eatr $(t-1)$} & $-0.119 * * *$ & -0.078 & $-0.073^{*}$ & -0.085 \\
\hline & $(0.043)$ & $(0.056)$ & $(0.039)$ & $(0.058)$ \\
\hline \multirow[t]{2}{*}{$\rho_{1}$} & $0.874^{* * *}$ & $0.817^{* * *}$ & $0.958^{* * *}$ & $0.775^{* * *}$ \\
\hline & $(0.222)$ & $(0.151)$ & $(0.219)$ & $(0.174)$ \\
\hline \multirow[t]{2}{*}{$\rho_{2}$} & $0.923^{* * *}$ & $0.847^{* * *}$ & $1.023^{* *}$ & $0.895^{* * *}$ \\
\hline & $(0.312)$ & $(0.315)$ & $(0.505)$ & $(0.266)$ \\
\hline \multirow[t]{2}{*}{$\rho_{3}$} & 0.016 & 0.023 & -0.023 & -0.297 \\
\hline & $(0.134)$ & $(0.101)$ & $(0.142)$ & $(0.182)$ \\
\hline \multirow[t]{2}{*}{ pp15 } & -0.002 & 0.007 & -0.005 & -0.012 \\
\hline & $(0.011)$ & $(0.010)$ & $(0.010)$ & $(0.016)$ \\
\hline \multirow[t]{2}{*}{ pp65 } & 0.000 & -0.009 & 0.008 & -0.009 \\
\hline & $(0.010)$ & $(0.009)$ & $(0.014)$ & $(0.009)$ \\
\hline \multirow[t]{2}{*}{ unempl } & -0.000 & 0.001 & -0.001 & 0.004 \\
\hline & $(0.004)$ & $(0.003)$ & $(0.005)$ & $(0.003)$ \\
\hline \multirow[t]{2}{*}{ dens } & -0.001 & -0.000 & -0.001 & $-0.003^{*}$ \\
\hline & $(0.001)$ & $(0.001)$ & $(0.003)$ & $(0.001)$ \\
\hline \multirow[t]{2}{*}{ log_reg_gdp } & -0.021 & -0.027 & -0.020 & 0.009 \\
\hline & $(0.060)$ & $(0.049)$ & $(0.055)$ & $(0.048)$ \\
\hline \multirow[t]{2}{*}{ trend } & -0.002 & 0.005 & -0.007 & 0.007 \\
\hline & $(0.016)$ & $(0.013)$ & $(0.017)$ & $(0.012)$ \\
\hline \multirow[t]{2}{*}{ trendsq } & 0.000 & 0.000 & 0.000 & -0.000 \\
\hline & $(0.002)$ & $(0.001)$ & $(0.002)$ & $(0.001)$ \\
\hline \multirow[t]{2}{*}{ fr_unempl } & -0.021 & -0.019 & -0.012 & -0.018 \\
\hline & $(0.025)$ & $(0.016)$ & $(0.033)$ & $(0.017)$ \\
\hline \multirow[t]{2}{*}{ fr_dens } & 0.001 & 0.000 & 0.003 & 0.003 \\
\hline & $(0.004)$ & $(0.002)$ & $(0.006)$ & $(0.003)$ \\
\hline \multirow[t]{2}{*}{ fr_pp15 } & -0.008 & -0.012 & -0.015 & -0.005 \\
\hline & $(0.034)$ & $(0.029)$ & $(0.053)$ & $(0.042)$ \\
\hline \multirow[t]{2}{*}{ fr_pp65 } & 0.032 & 0.014 & 0.003 & 0.013 \\
\hline & $(0.046)$ & $(0.029)$ & $(0.061)$ & $(0.035)$ \\
\hline \multirow[t]{2}{*}{ vertical_eatr } & -0.004 & -0.025 & 0.004 & -0.046 \\
\hline & $(0.049)$ & $(0.043)$ & $(0.074)$ & $(0.039)$ \\
\hline A-B test $\mathrm{AR}(2)$ (p-value) & 0.679 & 0.397 & 0.538 & 0.309 \\
\hline Hansen test (p-value) & 0.501 & 0.934 & 0.544 & 0.582 \\
\hline
\end{tabular}

$\mathrm{T}=8,20 \mathrm{~km} \mathrm{n}=347,30 \mathrm{~km} \mathrm{n}=602$, Number of instruments: 81

Standard errors in parentheses, $* * * \mathrm{p}<0.01,{ }^{*} * \mathrm{p}<0.05,{ }^{*} \mathrm{p}<0.1$ 